\title{
THE SUCCESS OF POLICY ADVOCACY IN PUBLIC DIALOGUE AS A POLICY MAKING
}

\author{
Bintan Aulia Habibah, Ramaditya Rahardian, Panji Windu Arista \\ Master of Public Policy, Faculty of Social Science and Political Science, Airlangga \\ University Surabaya, Indonesia \\ bintanauliahabibah@gmail.com,ramaditya_rd@yahoo.co.id,panjiwindu88@gmail.com
}

\begin{abstract}
The purpose of this study was to find out the success of policy advocacy in Public Dialogue as a policy making in Bojonegoro Regency. Based on the objectives, this research is a qualitative descriptive research which presents and provides a detailed description of the success of policy advocacy in Public Dialogue as a policy making. The research location was in the Office of Comunication and Information and Hall of Malowopati. A snowball technique was used to determine the informants. The method of collecting data was in the form of observation, interviews, and documentation. A triangulation technique was used to check the validity of the data. The Public Dialogue is an open space for the community and the Bojonegoro regency Government to communicate directly in order to influence the policy making. This research utilized an advocacy strategy from Roem Topatimasang to form a core circle, choose strategic issues, process data and information, influence policy makers, and monitor and assess programs. The research results found that Public Dialogue was one of the tools of the community to influence a public policy in Bojonegore Regency.
\end{abstract}

Keywords: Public Dialogue, Policy Advocacy, Public Policy

\section{Introduction}

The reform period requires a lot of changes, especially in the governance. One of them is the policy taken by the government no longer applies the top down model, but rather implements a bottom up policy model. Bojonegoro Regency is a regency in East Java Province which has implemented good governance practices. One of the indications is the implementation of public services by an effective, efficient, and accountable group of institutions. One of the innovations conducted by the Bojonegoro government is to hold a dialogue between the community and the Bojonegoro Regent and his staff every Friday. The dialogue takes place at the Malowopati Hall has been conducted since 2008, several days after Suyoto, the Bojonegoro Regent was inaugurated, until the end of his period. The public dialogue was initiated by Suyoto and was his political promise when he was elected as the Regent of Bojonegoro. Since 2008, regular dialogues have been conducted and attended by the community in a participatory manner from various community groups with various problems presented.

Bojonegoro's public dialogue is one of the implementations of the Public Information Disclosure Act number 14 of 2008. The PID Act basically regulates the rights and obligations of the public and government as executors of public services in managing public information. One of the objectives of the PID Act is to encourage community participation in the process of public policy making and increase the active 
role of the community in public policy making and the management of good public institutions. In the Bojonegoro's public dialogue, the residents who join the dialogue are citizens who participate in creating a change. According to (Sumarto, 2009), community participation is a process when citizens as individuals and social groups and organizations take part in influencing the process of planning, implementing, and monitoring policies which directly affect their lives. Bojonegoro community actively participates in a series of public dialogues by giving some input, feedback, or just discussing the problems at hand. Therefore, the participation carried out by the Bojonegoro community resulted in the part of the formulation of public policy. The series conducted by the residents of Bojonegoro was part of policy advocacy. Referring to the statement of Young and Quinn (2002), (Suharto, 2014) in Edi Suharto's book, there are seceral definitions of advocacy, particularly those relating to the analysis of social policies. They define an advocacy as processses involving a set of political actions carried out by citizzens who are organized to transform power relations. The aim of advocacy is to achieve policy changes which benefit the poeple involved in the process. Effective advocacy is conducted in accordance with strategic plans and within a reasonable time frame. Another view from (Sharma, 2016), policy advocacy is an act of individuals and collectives or organized community organizations, systematically trying to influence decision-making or policy in order to consider the participation of civil society better in each pf its policies.

Another definition according (Topatimasang, 2016), policy advocacy is an effort to improve or change public policies in accordance with the wishes or interests of those who push for such improvements or changes. (Topatimasang, 2016) outlines several stages and steps which must be taken in conducted the range of an integrated policy advocacy in order to include a group interest to become a public policy. Those steps include: (1) Forming a Core Circle, (2) Selecting strategic issues which will be advocated, (3) Designing targets and strategies, (4) Processing data and information, (5) Raising allies and supporters, (6) Proposing design matches, (7) Influencing policy makers, (8) Forming public opinion, (9) Building a base of movement, (10) Monitor and assess programs, (11) Program evaluation.

Research on public dialogue has been conducted by several researchers such as research on the rationalization of public dialogue forums in Bojonegoro Regency by (Solihatin Izzaty, 2016) which found that the forum for public dialogue was the result of the Regent's rationality as a political promise which used to be called sobo pendopo. Therefore, the actions of the Bojonegoro Regent are a rational act of purpose. The second study on the effectiveness of Public Dialogue as a deliberative public policy model in Bojonegoro Regency was written by (Habibah, 2017). In her research, Public Dialogue was seen as one of the indicators in making public policies involving the community. Moreover, research related to policy advocacy has also been examined by (Gen \& Conley Wright, 2013) through a research entitled Policy Advocacy Organizations: A Framework Linking Theory and Practice. This research explained that practitioners and academic literature synthesize policy advocacy and propose a 
conceptual framework for policy advocay inputs, activities, and results. The fifth article is from (Rennkamp, Haunss, Wongsa, Ortega, \& Casamadrid, 2017) analyzing political coalitions in support of and opposition to renewable energy policies in three middleincome countries such as Mexico, South Africa, and Thailand. Furthermore, there is an article written by (Prianto, 2013) which tries to see an advocacy coalition in the process of formulating spatial planning policies in Makassar during the period 2010 to 2030. The last article is wirtten by (Rahardian, 2018) which tries to look at the dimensions of the paralegal path approach conducted by labors and labor organizations in Surakarta in conducting policy advocacy to reject the Government regulation Number 78 of 2015 concerning labor wages. The above articles have discussed a lot about Bojonegoro's public dialogue and policy advocacy. However, the authors offer a side of renewal in terms of theoretical reviews which discusses the policy advocacy approach in Bojonegoro's public dialogue as an effort to incorporate the agenda of the interests of the community in policy making. This paper seeks to view the strategies of a policy advocacy conducted by the community and community groups in Bojonegoro.

\section{Research Method}

This article will examine the success of policy advocacy in Public Dialogue as a policy making. The location of this research is Bojonegoro Regency, precisely in Pendopo Malowopati. Moreover, the type of this research is a qualitative descriptive which emphasizes the process and meaning. The sampling technique is a purposive technique followed by a snowball technique. The data collection is conducted through an observation and interview with the community who attended the Public Dialogue forum and reviewing documentation from several electronic media such as the internet. A data triangulation technique is conducted to test the validity of the data in this research through collecting data from various different sources regarding the problems studied to be compared. The data analysis technique is conducted by reducing, presenting data, and drawing conclusions.

\section{Discussion}

One of manifestation of the democracy practice in public service is to provide opportunities for the public to submit complaints or suggestions when the services they receive are not in line with expectations or not in accordance with the promise of the service provider. The government of Bojonegoro Regency conducts a public dialogue which brings the government together with the community directly for a dialogue. In this dialogue, the community is free to convey all their complaints so that what they want may be realized by the government. This dialogue is included in the series of policy advocacy. Individuals or groups in Bojonegoro Regency have several advocancy strategies to support the success of the public dialogue as a policy making, which include: 


\section{A. Forming a Core Circle}

The Bojonegoro regency government routinely conducts public dialogue on Friday. In this forum, there are core members who always present to succeed the Public Dialogue such as the Regent of Bojonegoro, Deputy Regent of Bojonegoro, Regional Secreatry, and all heads of the Bojonegoro Regional Work Unit (SKPD). The communities of Bojonegoro Regency consist of various alliances or groups to fight for the interests of each group. The groups or alliances are consisting of agriculture groups, cattleman groups, disabled people as well as the general public. Each individual or group always carry their own agenda to influence policy makers, the Regional Government of Bojonegoro Regency.

\section{B. Choosing Strategic Issues}

In the implementation of the Public Dialogue, the Bojonegoro Regency Governemnt has a different theme each week by presenting several related public organizations or service providerss in accordance to the problems faced by the individuals or community groups in Bojonegoro. In each discussion and submission of information, every element of society, both individuals and groups, always convey several ideas, suggestions, critisms, and protests in the fields of agriculture, fisheries, animal husbandry, forestry, public works, social affairs, and education in Bojonegoro. This public dialogue is used by individuals and groups to convey the strategic issues relating to urgent problems in Bojonegoro.

\section{Influencing the Policy Makers}

In its efforts to include the agenda and interests of individulas or community groups, those who attend the public dialogue on Friday conduct a series of activities. The series begins with an audience with organizations or public institutions which are related to the problems faced by these individuals or groups. After that, they submit their ideas or protests related to policy making and its implementation. The last is to lobby and negotiations around the public policy which will later be made by the Bojonegoro Regency Government so that the public policies are made in accordance with the wishes of individuals or groups in Bojonegoro Regency who insist on them.

\section{Monitoring and Evaluating the Program}

Through the Public Dialogue, the Bojonegoro community participate in monitoring and evaluating the programs which will be created and being conducted by the Bojonegoro Regency government. The analysis of community data and information is enriched by conducting focus discussion group with the Regional Work unit (SKPD) and institutions related to the public information. The results of data analysis and discussion are compared to the principles and mandate of the Public Information Disclosure Act to obtain conclusions and provide recommendations for users of the results of this research, namely the Bojonegoro Regency Government. If the public policies are not in accordance with the wishes and desires of the community, the 
community or groups will return to the Friday Public Dialogue forum to oversee the policies which have been made to suit their wishes.

\section{The Results of the Policy Advocacy}

Based on the whole set of policy advocacy strategies conducted by the several elements of society both individually or in the groups above, the policy advocacy conducted in the Public Dialogue forum which is routinely held on Friday has produced several positive results for the Bojonegoro community in public decision making or public policy making. Several examples of the results of public policy which are influenced by the involvement of the community are the policy on farmer cropping patterns, development of forest area roads, control of street vendors, RASTRA or raskin policy, and Regent Regulation number 18 of 2012 concerning Water-using Farmer Association.

\section{Conclusion}

The dynamics of openness in Bojonegoro are felt right because the community feels its aspirations are heard and responded to by the government without any fear and worry. By understanding the importance of community aspirations, in-depth studies are needed through advocacy strategies by forming a core circle, choosing strategic issues, processing data and information, influencing policy makers, and monitoring and evaluating programs. The results of the study are expected to be a valuable input for the government in an effort to answer the real needs which exist in the community. Therefore, the development conducted every year in Bojonegoro Regency and its results are a reflection and tangible manifestation of fulfilling the life needs of the people. Furthermore, the regency government will be able to make a better mid-term and long-term development planning because of the transparency and openness of the information. In the end, the local government who carries out the mandate of its people is not only having a strong commitment, smart and responsible, but also being able to listen and answer the aspirations of the people in a wise manner. Moreover, the people involved in this policy advocacy also open and create a good governance because it is able to present the community participation in every policy formulation in Bojonegoro Regency.

\section{Acknowledgement}

The authors are very grateful to the Regional Government of Bojonegoro Regency and various layers of community groups for the information and cooperation given for this research.

\section{References}

Gen, S., \& Conley Wright, A. (n.d.). Policy advocacy organizations: A framework linking theory and practice. Journal of Policy Practice, 12(3), 163-193. 
Habibah, B. A. (2017). Efektivitas Dialog Publik Sebagai Model Kebijakan Publik Deliberatif Di Kabupaten Bojonegoro. Administrasi Negara Universitas Airlangga.

Prianto, A. L. (2013). Model of Advocacy Coalitions in the Formulation of Spatial Plan Policy of Makassar in 2010-2030. Bisnis \& Birokrasi Journal, 20(3), 163-170. Retrieved from http://journal.ui.ac.id/index.php/jbb/article/view/3205

Rahardian, R. (2018). Evaluating The Use of Paralegal Approach in Policy Advocacy, 22(78), 14-19.

Rennkamp, B., Haunss, S., Wongsa, K., Ortega, A., \& Casamadrid, E. (2017). Competing coalitions: The politics of renewable energy and fossil fuels in Mexico, South Africa and Thailand. Energy Research and Social Science, 34(August), 214-223. https://doi.org/10.1016/j.erss.2017.07.012

Sharma, R. R. (2016). An Introduction To Advocacy. Training Guide. Support The Analysis Research In Africa (SARA), Health And Human Resources Analysis For Africa (HHRAA). US Agency For International Development.

Solihatin Izzaty. (2016). Rasionalisasi Forum Dialog Publik Di Kabupaten BOjonegoro. Universitas Airlangga.

Suharto, E. (2014). Analisis Kebijakan Publik, Panduan Praktis Mengkaji Masalah Dan Kebijakan Sosial. Bandung: Alfabeta.

Sumarto, H. S. (2009). Inovasi, Partisipasi Dan Good Governance. Jakarta: Yayasan Obor Rakyat.

Topatimasang, R. (2016). Mengubah Kebijakan Publik Panduan Pelatihan Advokasi. Yogyakarta: Insist Press. 